\title{
The Contributors
}

DAle CARTER is Associate Professor of American Studies and Chair of the Board of Studies at the Department of English, University of Aarhus, Denmark. His published work includes The Final Frontier: The Rise and Fall of the American Rocket State (1988) and (as editor) Marks of Distinction: American Exceptionalism Revisited (2001). He is currently writing a full-length study of the songs of Van Dyke Parks.

VANESSA CHANG is a writer, teacher and traveller who has made her home in a variety of landscapes, from China to Australia, Singapore to India, among others. She is currently looking for her next one. Previously found wandering the halls of the University of Chicago, her research interests include cultural theory, theories of media, semiotics, James Joyce, and electronic music.

ANNE DANIELSEN is a researcher in the Department of Musicology at the University of Oslo and head of the research project, 'Rhythm in the Age of Digital Production', investigating micro-rhythmic relationships and the impact of digital music technology on groove-oriented popular music of the 1990s. She is the author of Presence and Pleasure: the Funk Grooves of James Brown and Parliament, and has published articles in Popular Music and Studia Musicologica Norvegica.

CHRISTOPHER DUNN is Associate Professor and Chair of the Department of Spanish and Portuguese at Tulane University in New Orleans. He is the author of Brutality Garden: Tropicália and the Emergence of a Brazilian Counterculture (UNC Press, 2001) and co-editor of Brazilian Popular Music and Globalization (Routledge, 2001).

LARS ECKSTEIN is Assistant Professor of English at the University of Tübingen, Germany. Recent publications include Re-Membering the Black Atlantic: On the Poetics and Politics of Literary Memory (Rodopi, 2006), The Cultural Validity of Music in Contemporary Fiction (ed. with Christoph Reinfandt, Special Issue, ZAA, 54/1, 2006), and English Literatures Across the Globe: A Companion (ed., UTB, 2007). He is currently working on a project entitled, Song Texts: A Cultural Rhetoric of English Lyrics.

ARnT MAAsø is Associate Professor and Director of Studies at the Department of Media and Communication at the University of Oslo, and is currently involved in the research project, 'Participation and Play in Converging Media', studying non-professional participation in the media, and technological developments facilitating audience participation. He has published widely on the role of sound in film and television in Norwegian, with some articles translated to English, German and French.

YASSER MATTAR is a sociologist at the National University of Singapore. He researches on the culture of economics and the economics of culture. He is also trained as a teacher of English as a foreign language.

AKSEL TJORA is Professor in Sociology at the Norwegian University of Science and Technology (NTNU), Department of Sociology and Political Science. His research is 
focused on the interaction between users and technologies in a wide range of areas, such as health, communication, architecture, music, within organisations and in public space. He also composes music and plays drums in various local bands. 